Some Judicial Experiences in the Light of

The Principle of Easy-Access to Justice to

Settle Small Civil Claims:

Egypt - France - Emirates

\title{
BY
}

Dr. Sahar Abdel-Sattar Emam

Professor of civil procedure law

Dean of faculty of law

University of Sadat city 


\section{Some Judicial Experiences in the Light of \\ The Principle of Easy-Access to Justice to \\ Settle Small Civil Claims: \\ Egypt - France - Emirates}

\section{Introduction}

The rule of law is one of the main principles of countries, the basis of government, and the key to stability upon entering into force against each and every one. Such principle is based on the following rules:

1) Independence and fairness of judiciary,

2) Granting the right of litigation and resorting to court for people on low income,

3) The right of fair and equitable trial,

4) Easy-access to justice,

5) Forbidding the exclusion of the administrative orders from the judicial supervision,

6) Ceasing the operation of courts of exceptional jurisdiction and granting the right of court resort,

7) Enforcing the judgments in the name of the people, provided that; the country shoulder the responsibility of enforcement. $\left.{ }^{1}\right)$

The present paper aims at shedding light on the principle of "Easy-Access to Justice" - the main basis of the principle of the rule of law being a constitutional requirement. The country shall grant the right to litigate and overcome any obstacles that prevent access thereto if there is a need to resort 
to court asking for effective judicial protection which has as many forms as the type of violating the legal status or the legal right may be. $\left({ }^{1}\right)$. The court does not interfere unless the law has been broken since the court has been deemed the observer and the interpreter of law $\left(^{2}\right)$.

Applying the principle of easy-access to justice requires numerous onelevel courts. One court is not enough to provide the effective judicial protection for all litigants, especially with the expansion of the country at the regional level and the overload of the backlog of multiple cases. One-level courts shall be spread along the country to make it easier for litigants to access to justice avoiding transportation to places far away from home.

The present paper tackles different experiences of applying the principle of easy-access to justice in Egypt, France, and Emirates. These countries tried so hard to overcome any obstacles that hinder accessing to justice by establishing nearby courts of litigants with easy procedures, and less costs as shown below:

First chapter: The Egyptian Experience

Second chapter: The French Experience

Third chapter: The Emirates Experience

${ }^{1}$ Articles 94:100 of Part Four of the Egyptian Constitution, 2014.

${ }^{2}$ Ragheb, W. (2004). The principles of the Civil Judiciary. $4^{\text {th }}$ edition, Dar El-Nahda ElArabia, p. 40. 


\section{First chapter}

\section{The Egyptian Experience}

The Egyptian legislature adopted the principle of easy-access to justice and tried so hard to apply it to grant the right of litigation and eradicate any obstacles that may hinder such application. The legislature attempted the horizontal expansion of the one-level courts in all Egypt's regions.

As an exception, the Cairo-based Cassation Court $\left({ }^{1}\right)$ is designated with the purpose of creating a central tool to exclusively interprets the law, appropriately applies it, harmonizes such interpretation with the other courts, and achieves the uniform of the legal principles of the country applied by the courts, which in turn establish and promote justice since the uniform of the interpretation of law attains equity among litigants $\left({ }^{2}\right)$. As a consequence, the distinctive nature of the Cassation Court; the guide to the legislative power (La gardienne du pouvoir législative), is derived from its mission which is confined to uniform the interpretation of laws and ensure applying them accordingly by the courts of lower rank (la cour régulatrice) $\left({ }^{3}\right)$. Apart from the Cassation Court, the courts of appeal are spread every where $\left({ }^{4}\right)$ There

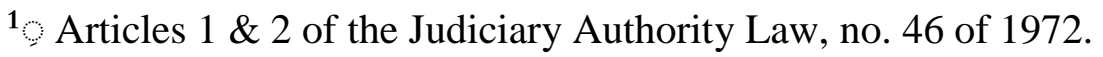

${ }^{2}$ Hindy, A. (2006). The Cassation Court: Judgements, Effects, and Legal Force. Dar Elgamaa El-Gedida, p. 280.

${ }^{3}$ La loi du 1re décembre 1790 pour la formation d'un tribunal de cassation: lois et actes du gouvernement T.2 (1866) P. 156.

Emam, S. (2014). Mechanics of Promoting the Role of the French Cassation Court in Achieving Justice: Request of Petition for exceeding the Power. Dar Elgamaa El-Gedida, pp. 18.

${ }^{4}$ Article 6 of the Judiciary Authority Law, no. 46 of 1972. 
are 8 courts of appeal in Egypt. They may be held, upon a decision by the ministry of justice and a request from the president of the court of appeal, in or out any other place of jurisdiction if need be. A circuit of appeal may permanently be held in each court of first instance upon a decision by both the ministry of justice and the general assembly of the court of appeal $\left({ }^{1}\right)$ to make it easier for litigants due to the regional expansion of the courts of appeal which exist in more than one government. Consistently, a court of appeal is established together with a number of courts of first instance located in the same region $\left({ }^{2}\right)$.

Courts of First Instance: The distribution and the regional jurisdiction of the courts of first instance depend on the nature and the type of the court. As a general rule, there is a court of first instance in the capital of each governorate. The issuance of the presidential decree no. 93 of 2015 has amended the jurisdiction of some courts of first instance and has established new courts of first instance $\left(^{3}\right)$. Correspondingly, there is more than one court of first instance in some governorates (e.g. Cairo, Alexandria, Tanta, Banha ...) while there are district courts in every city's district and towen.

Courts of Summary Proceedings: Such courts temporarily consider urgent matters that cannot be delayed. Although some of the legal processes are dispensed with, fundamental rights must be observed. The summary courts exercise the jurisdiction of the district courts and are ordinarily available for cases that require prompt action $\left({ }^{4}\right)$.

${ }^{1}$ ibid.

${ }^{2}$ Moslim, A. (1969). Fundamentals of the Civil and Commercial Code of Procedures. Dar El-Fekr El-Arabie, Clause 185, p. 191.

${ }^{3}$ Decree on Law 93 of 2015. The Official Gazette, 33 (b) cont. August 13 ${ }^{\text {th }}, 2015$.

${ }^{4}$ If a case is fully brought for speedy disposition of a matter, courts of summary proceedings shall have the first competent authority. If a case is partially brought for 
Courts of Execution of Judgments: Courts of execution of judgments is a district court competent to consider disputes of summary and ordinary execution of judgments, no matter the value of the case under Article 275 of the Civil and Commercial Code of Procedures $\left({ }^{1}\right)$.

The minister of justice has been vested by the legislature to issue decisions of establishing district courts competent to consider certain types of cases specifying their locations and jurisdictions $\left({ }^{2}\right)$. Correspondingly, the minister of justice issued a number of decisions to establish district courts competent to consider commercial and labor disputes and designated their scope of jurisdiction $\left({ }^{3}\right)$.

The legislature was flexible in vesting the minister of justice the right to specify the district courts' locations and territorial jurisdictions in such industrial zones according to the industrial activities. Therefore, nearby

speedy disposition of a matter, the trial court shall have jurisdiction to consider the case and courts of summary proceedings shall have partial competent authority.

${ }^{1}$ It is worth to note that Articles 274 and 275 of the Civil and Commercial Code of Procedures have been amended by law no. 76 of 2007. The Department for the execution of judgments shall, under said law, supervise and follow up execution, overcome any obstacles, entitle the director or staff to issue decision and orders related to execution, and directly and administratively supervise the arbitrary execution. However, the judge has a specific competence in solely the settlement of summary and ordinary legal disputes in reasonable time establishing the desired justice.

${ }^{2}$ Article 13 of the Judiciary Authority Law no. 46 of 1972.

${ }^{3}$ In 1940, two commercial district courts have been established within the jurisdiction of the Cairo and Alexandria Courts of First Instance. Accordingly, the other district courts within the jurisdiction of said two courts are no longer competent to consider such matters. In 1953, labor district courts have been established within the jurisdiction of the Cairo, Alexandria, Kaliobia, and Poert Said Courts of First Instance. For more information, see Moslim, A. (1969). Fundamentals of the Civil and Commercial Code of Procedures. Dar El-Fekr El-Arabie, Clause 117, pp. 103-104.

It is worth mentioning that specialized courts of exclusive jurisdiction have been established to consider economics claims under Law no. 120 of 2008 and labor courts under Law no. 180 of 2008. Accordingly, the labor and commercial district courts are no longer competent to consider such matters - the economic and labor courts have the specific jurisdiction. For more information, see The Economic Courts under the Egyptian Law. Dar El-Nahda El-Arabia, 2008. Barakat, A. (2009). Litigation before Labor Courts. Dar El-Nahda El-Arabia. 
courts of litigants have been established to settle disputes related to such activities. The courts are nothing more special than being district courts competent to consider certain types of cases within certain territorial jurisdiction. Nevertheless, it is a significant and excellent step to make it easier for litigants to resort to courts not far from their homes. The second step was the establishment of nearby specialized courts of litigants under law no. 10 of 2004. As a consequence, family courts of the same local jurisdiction of each district court have been established to exclusively settle family disputes. The location of the family courts shall be designated by the minister of justice and such courts may, if need be, be held in any other place in or out their territorial jurisdiction under Article 1 (3) of law no. 10 of 2004.

Designating the territorial jurisdiction of the family courts as stated above is in agreement with the principle of making it easier for litigants to resort to courts not far from their homes taking into consideration litigants' circumstances and transportation's time, effort, and costs. As a result, there is a family court in the territorial jurisdiction of each district court, i.e. in each markaz owing to the varied types of family dispute (1). In addition, the legislature has tailored specific procedures for the family courts suitable for such type of disputes which need nearby courts of litigants able to eradicate the disputes, maintain families, and prevent family breakdown $\left({ }^{2}\right)$.

As stated earlier, the Egyptian legislature has coined in the constitution, and practically translated the principle of establishing nearby courts of litigants. Granting the right of litigation by overcoming any obstacles that

\footnotetext{
${ }^{1}$ Khalil, A. (2000). Litigation issues of personal status law concerning legal guardianship under Law no. 1 of 2000. Dar El-Matboat El-Gameia. Emam, S. (2004). The Family Court. Dar El-Nahda El-Arabia.

${ }^{2}$ Explanatory Note to Family Law no. 10 of 2004.
} 
could prevent litigants from easily access to justice was firmly established in the legislature's mind long time ago.

Best efforts have been exerted to consider small criminal and civil claims and meet people's needs and wishes. In an attempt, non-technically qualified magistrates elected from the elite group of people were assigned to settle disputes and cases for free. Considering small-claims, such attempts relieved the case backlog and were easy, fast, and inexpensive as compared to any man-made rules and/or restrictions $\left({ }^{1}\right)$. Below is an exhaustive list of such attempts:

El-Daawy Councils: El-Daawy councils had been established in 1870. They were composed of and directed by Sheikh El-Balad together with two persons therefrom. Such councils were existed in every village. Members were elected by nomination and were vested the right to settle disputes arisen among farmers on boarders, irrigation, joint ownership of animals, workers' wages, all civil claims less than EGP 5, and misdemeanors. Judgments held by these councils were appealed before higher council located in each Markaz $\left({ }^{2}\right)$. El-Daawy councils were cancelled in 1883 and replaced by the courts of first instance, district courts, and courts of appeal.

Al-Akhtat Courts $\left(^{3}\right)$ : In 1892, 40 district courts were established and in 1904, they were further expanded. Unfortunately, the district courts established so far were not enough to meet people's needs in each Markaz and within the same vein, judges suffered from the heavy caseloads and delay. Therefore, new courts (Magales El-Solh) lower than the district courts

\footnotetext{
${ }^{1}$ The Report of Nezaret El-Hakania's Judge, 1912, pp. 16, as cited in El-Said, A. (n.d.). Handbook of the Civil and Commercial Code of Procedures. Dar El-Fekr El-Arabie. ${ }^{2}$ Abo Heif, A. (1921). The Civil Code of Procedures. 2nd edition.

${ }^{3}$ Omar, M. (1972). Non-Official Judiciary in Egypt. Journal of Masr El-Moasra, 347, 5976. Ibrahim, M. The General Theory of the Non-Official Judiciary. Unpublished PhD Dissertation, Faculty of Law, Ain Shams University.
} 
were established by Law no. 11 of 1911 under the supervision of the district courts' judges. The courts were competent to consider small civil claims (e.g. real property claims less than EGP 10, waterwheel ownership and usufruct claims, and farmland lease and possession claims). Litigants did not have to be represented by lawyers and the judgments held by such courts were final for claims less than certain monetary threshold.

At the beginning, Al-Akhtat Courts succeeded in relieving the case backlog, reducing costs and expenses, easily accessing to justice, and making it easier for litigants to go to courts not far from their homes. Specifically, such courts were suitable to farmers who need to spend most of the day in the land not in pursuing their claims in the district court. However, in 1930, the Egyptian legislature cancelled Al-Akhtat Courts due to the following reasons $\left({ }^{1}\right)$ :

1) Failing to attain the desired goals.

2) Encountering many problems in finding persons qualified enough to work therein by the executive power.

3) Failing to solve such problems and lacking an effective policy to compel court members to be persistent in their work and in enforcing law satisfactorily, and

4) Being a source of complaints and spoils

Later on, the legislature widely established district courts in each town and markaz to be close to litigants with specific jurisdiction to consider small 68. 
civil disputes $\left({ }^{2}\right) \cdot\left({ }^{1}\right)$ in addition to the pecuniary jurisdiction to consider claims not exceeding EGP $40000\left({ }^{3}\right)$.

Accordingly, the idea of establishing nearby courts to litigants can practically be seen in the district and family courts, i.e. the small civil claims in terms of the facts of the case and the value, and the family claims.

\section{Second chapter}

\section{The French Experience}

The French legislature applied the principle of "nearby courts to litigants" by establishing courts competent to consider small civil claims under law $\mathrm{n}$. 16 of 1790 - the judge of peace / settlement (Juge du Paix). The judge firstly acted as a mediator assisting the parties to negotiate a settlement and secondly, as a judge holding a decision upon failing to mediate the dispute. Though achieving great success, the "judge of peace" was cancelled especially in rural areas $\left({ }^{4}\right)$ and was replaced by judges of district courts under Article 1, law no. 58-1273 of 1958. The district courts were competent to decide wide variety of cases (e.g. claims on plants damage, local elections, terms and expenses of funerals, and costs and expenses of divorce). Notably, the judges were competent to consider wide variety of small daily claims encountering serious overload backlog cases. As a result, the legislature came up with the idea of establishing close courts to litigants (La juridiction de proximité) competent to consider small criminal and civil claims $\left({ }^{5}\right)$ with

\footnotetext{
${ }^{1}$ Article 43 of the Civil and Commercial Code of Procedures No. 13 of 1968 as amended. ${ }^{2}$ Wally, F. (1991). Towards a New Mechanism for Settling Small Civil Claims. The Egyptian-French Joint Symposium on Settling Small Civil Claims by legislation and modern techniques. The National Center for Judiciary Studies.

${ }^{3}$ Article 43 of the Civil and Commercial Code of Procedures No. 13 of 1968 as amended. ${ }^{4}$ P.Estoup:, le bicentenaire oublié du juge du paix, gaz pal. 20 déc. 1990, Doct; H.Vieille, le rôle judicaire et social du juge de paix, thèse. Paris 1944; M. Dor, le juge de paix, magistrat, familial, thèse. Dijon, 1937.

Christian Bolze etPhilipe Perdot: les juges uniques dispersion ou réorganisation du ( ${ }^{\circ}$ contrnieux ,Dalloz 1996
} 
the purpose of relieving case-load pressures. The courts were competent to settle small daily claims (Petites Litiges de la vie quotidienne) which do not require long time, great efforts, or legal research and analysis to be resolved. The procedures thereof were easy, quick, and inexpensive aiming in the first place to settle a dispute by conciliation between parties thereto and in the second place to hold a decision upon failing to reach an agreement (1).

The nearby courts are courts of first instance with the local jurisdiction of the district courts. Being a good example of the local justice $\left(^{2}\right)$, small courts were established everywhere to be close to the place of any probable dispute and for better grasping of the arising issue $\left({ }^{3}\right)$. Such nearby courts were not only geographically and locally close to litigants, but also personally and phsychologically close. The magistrates can move to the area of the dispute if need be, negotiate the controversy with the litigants, and reach a fair and equitable mutual agreement $\left({ }^{4}\right)$ based on facts practically examined not deduced from mere reading of the legal documents $\left({ }^{5}\right)$.

Some legal theorists believe that the nearby courts as a model taken from the French legal system, give a good impression of how the French judiciary is effective, quick, and fair (une justice plus efficace). additionally, the nearby courts have a deep social role in amicably eliminating the disagreement between the parties by virtue of the good relations existing between the judge and the litigants. Providing deep insight into such courts,

${ }^{1}$ Marc véricel, pour une véritable justice de proximité en matière civile , J.C.P. , n 10 , 5 Mars, Doctrine , 1, 114.

${ }^{2}$ Omar, M. (1976). The Civil Judiciary System: Part One, General Rules.Dar El-Nahda El-Arabia. $1^{\text {st }}$ edition, pp. 45.

${ }^{3}$ H.Moutouh, la juridiction de proximité, une tentative de déconcentration judiciaire, D. 2002. P. 31218.

${ }^{4}$ Martine Fabre, vincente Fortier, "Le juge de proximité, une nouvelle offre de justice? Droit et justice, no26 printemps- Eté 2007.

${ }^{5}$ Hubert Haenel, Justice de Proximité, Pouvoirs, 74. 1995;N.Kamare:Date d'effet de suppression de la juridiction de proximité. Les petites affiches, décembre 2016. 
below is a detailed description of such courts' structure, organization, procedures, judges, competence, and the binding legal force and effect of its judgments.

\section{- The Structure of the Nearby Courts (1)}

The nearby courts are composed of one judge who was elected from:

1) Retired judges of ordinary or administrative judiciary,

2) Lawyers of no less than twenty five years of experience in the field of law,

3) Judicial officers and employees of the Ministry of Justice, and

4) Expert mediators of no less than five years of experience.

Upon filing a request to be a judge in the nearby courts, applicants must be at least 35 years, have at least 4 years of experience in the field of law, be or were members of the Egyptian Bar Association.

In case of fulfilling any of the above conditions, an applicant may be a judge in the nearby courts no matter of being a professional judge already appointed in the Egyptian judiciary system or even of holding a law degree. Experience and competence are of the utmost importance $\left(^{2}\right)$.

\section{- Mechanism of Appointment}

The courts of appeal shall review the applicants' files prior to submitting them to the Minister of Justice who has the discretionary authority to ask for more requirements, elect the qualified judges, introduce them to the Supreme Council of Judges (Conseil supérieur de la magistratures), and finally issue

\footnotetext{
${ }^{1}$ Association nationale des juges de proximité : http://www.anjp.fr/qu-est-ce qu-jugeproximité.htm/.

${ }^{2}$ The nearby courts are as the Courts of Farm Leases, Courts of Social Insurance, and Labor Councils are formed from a mixed of non-professional and professional judges. However, The Commercial Courts are confined to non-professional judges. For more information, see Emam, S. (2005). Towards Judges' Specialization System. Dar ElNahada El-Arabia, pp. 61-74. The Commercial Courts under the French Law. Dar ElNahada El-Arabia, 2014.
} 
a presidential decree of their appointment upon the approval of the Supreme Council of Judges. ${ }^{1}$ )

The recently appointed judges shall take a training course on the mission and tasks assigned to them prior to carrying out their job $\left({ }^{2}\right)$. However, a judge may be exempted therefrom by the Supreme Council of Judges if he has a distinguished prior judicial experience.

\section{- Term of Appointment}

The judges of the nearby courts are appointed for a term of 7 unrenewable years till reaching the age of 75 years. They can resign by virtue of a request submitted to the Supreme Council of Judges or be discharged thereby under the relevant law.

\section{- Continuing Professional Development}

All the judges of the nearby courts even those exempted from the preparatory course shall attend a course organized by the National Judicial College (Ecole Nationale de la Magistrature) to gain the theoretical and practical bases of the judiciary work. The course includes the judge's conduct, procedural rules, the art of writing and editing judgments, and hearing management.

The professional development continues along the judge's work for the 7 years. The judge attends a mandatory annual 5-day course in the first three years. The goals of the continuing training courses are to

1) grasp the ethics of the judicial work,

2) apply the law and follow the sound procedures,

3) respect the individual freedom,

${ }^{1}$ Law on the organization of the job of judges of the nearby courts, issued in February 26, 2003.

${ }^{2}$ La loi organique no2007-287 du mars 2007 sur le statut de la magistrature et a institué un stage probatoire obligatoire. 
4) Ensure their independence, fairness, and objectivity.

\section{Extra Work Duties}

The judges of the nearby courts are part-timer (temps partiel) who can do another job at the same time provided that both are not contradicting (e.g. general agency, public service, mediation, and public prosecution). Everyone works in this field is not entitled to be a judge of the nearby courts. However, lawyers, authorized agents, notary public, process servers, the Commercial Court registrars, syndics, the judicial liquidators, and the administrative staff of the Ministry of Justice are entitled to be a judge of a nearby court of first instance of different territorial jurisdiction $\left({ }^{1}\right)$. Therefore, the applicant should expressly state the nature of his current profession to prove that it will not prevent him from being fair, independent, and objective. Furthermore, a judge of the nearby courts may not settle disputes personally relevant to him or to his profession $\left({ }^{2}\right)$.

\section{Consideration}

Under Decree no. 17 of 2007, a judge of a nearby court is entitled a consideration up to Euro 2000 annually. Being a voluntary work, this consideration has grossly underestimated their precious efforts.

\section{Legal Status}

Law no. 153 of 2003 has organized the legal status of the judges of the nearby courts. They are part-timers appointed for a term of 7 unrenewable years. Being a voluntary work and receiving underestimated consideration, they do another job in addition to their job as judges of the nearby courts. Moreover, unlike judges of the ordinary courts, they may not hold a law

${ }^{1}$ Le juge de proximité " un citoyen au service de justice". Sites internet "association national des juges de proximité +: http: www.an JP. Fr.

${ }^{2}$ A. Art 2 al3 du décret no78-381 du 20 mars 1978 et Art. R. 15-33-33 du code de procédure pénale. 
degree or be promoted. However, they enjoy certain privileges and immunities similar to those of the professional judges (L'absence d'avancement) $\left({ }^{1}\right)$. For example, judges of the nearby courts

1) may only be legally discharged,

2) are subject to the legal supervision of the president of the Appeal Court and the judge of the district court located in his jurisdiction,

3) are subject to effective evaluation and follow up by the president of the court of first instance,

4) may be disciplined in case of technical and professional invalidity before a committee of the Supreme Council of Judges competent to legally question professional judges $\left({ }^{2}\right)$.

\section{Jurisdiction}

Law no. 47 of 2005 set forth the nearby courts' terms of reference as follows:

\section{1) Subject Matter Jurisdiction}

Civil Claims: the nearby courts have subject matter jurisdiction over the civil claims. However, they are not competent to consider the summary proceedings or the counter claims that fall within the specific jurisdiction of other courts. Broadly speaking, the nearby courts are competent to consider

- Claims and immovable claims not exceeding the value of Euro 4000 against natural persons (personnes physiques) whether the pleading submitted are in connection to the personal or the professional life,

- Claims brought against legal persons like a company or an organization (Personnes morales),

\footnotetext{
${ }^{1}$ Roger Perrot : Institution judicaire, 12ed 2006, Montchrestien, p 109

${ }^{2}$ Haddad sabine, juge de proximité : une suppression différée à janvier 2017, site internet: http: //www. Conseil juridique. Net - 1372. Htm.
} 
- Unassessable claims not exceeding the value of Euro 4000 (e.g. breach of a sale agreement),

- Writs of performance not exceeding the value of Euro 4000,

- Conciliation agreements not exceeding the value of Euro 4000,

- Lease claims not exceeding the value of Euro 4000.

\section{Criminal Claims}

The nearby courts have the jurisdiction to consider crimes related to press freedom, defamation claims, and misdemeanors not exceeding Euro 750.

\section{2) Local Jurisdiction}

Under Article R231-6 of the Judiciary Act, the nearby courts' territorial jurisdiction over civil claims follows the applicable rules of the district courts. Hearings may be held in important neighborhoods and rural areas if need be.

\section{Procedures}

The procedural rules of the district courts are followed before the nearby courts. Though the judges are independent, they may refer the case to the district courts for considering serious legal issues (Difficulté juridique sérieuse). Hearings may be held in the courtroom or in any other place (Des Audiences foraines). The plaintiff may apppear before the court with or without a representative (a lawyer) without a power of attorney or a private proxy. Nonetheless, spouse, parents, or relatives of first, second, and third degree may appear before the court on behalf of the plaintiff with a power of attorney or a private proxy. The judge shall respect the oral advocacy, the confrontation between the opposing parties, and the sound procedures of serving the legal documents.

\section{Legal Force of Judgments}


Following the hearings and the litigants' oral arguments, the judge may immediately or afterward decide the case no later than the legal term of 3 months commencing from the date of the end of the procedures. The judgment is final and irrevocable and shall be sent to each party. If the nonprevailing party willfully rejects to execute the judgment, the prevailing party may arbitrarily execute the judgment with the assistance of the officer of enforcement.

\section{Challengability of Judgments}

The decision made by the nearby courts is unchallengeable unless the claim is non-pecuniary. However, the decision is challengeable by nonordinary methods stipulated in law as follows: 1) a motion for reconsideration in case of cheating, deception, and fraud; and 2) challenge through cassation as stated by $\operatorname{law}\left({ }^{1}\right)$.

\section{Evaluation of and the French Attitude Toward the Nearby Courts ( $\left.{ }^{2}\right)$}

Establishing the nearby courts was widely accepted and promoted at the outset by French theorists for being a respond to the constitutional call and the legal principle - easy-access to justice - according to which litigants can easily access to nearby courts and no longer encounter transportation problems.

In addition, the nearby justice is not only physically but also emotionally close to litigants. Judges can easily communicate with litigants and move to different areas to solve the dispute as arises. Therefore, the judgment is completely fair and practically reflects the core of the issue. Nevertheless,

${ }^{1}$ La procédure devant le juge de proximité : www. Demander justice. Com / juridictionproximité.

${ }^{2}$ Les juridictions et juges de proximité " leur rôle concret en matière d'accès à la justice des petites litiges civils centre de Recherches critiques sur le droit, Décembre 2008. 
the nearby justice, as stated by the theorists, suffers many drawbacks as follows:

- The nearby courts are composed of non-professional judges. Holding nonlaw degree adversely affected their legal ability and qualification, regardless of any preparation or training received at the National Judicial College following the acceptance of working as a judge in the nearby courts $\left({ }^{1}\right)$.

- Insufficiency and non-objectivity of criteria set forth by law no. 153 of 2003 on working as a judge in the nearby courts causing partiality and courtesy $\left({ }^{2}\right)$.

- In availability of the nearby courts' judges and performing two jobs or professions at the same time aroused suspicions and doubts. Despite restrictions set by the legislature on managing two jobs, these restrictions are not sufficient and do not guarantee the objectivity, independence, and impartiality of judges.

- No-professionalism and inexperience of the nearby courts' judges were clearly obvious in their inability to run, manage, and conduct the hearings. $((3$

- Lack of privacy in the litigation procedures as compared to the district courts. However, the nearby courts follow all the rules governing the district courts (e.g. the procedures, the judges' panels, having secretary and registrar, holding hearings everywhere as the dispute may be, and conciliation). Hence, the nearby justice is not distinct as per the type of disputes authorized to consider.

${ }^{1}$ J.S. Boedels, le costume de juge de proximité, gaz. Pal mai- juin 2003, Doct. 1472.

${ }^{2}$ Le conseil constitutionnel, commentaire sur cette loi, J.C.P.N ${ }^{\circ} 10$ mars 2003, Actualité 123-127.

${ }^{3}$ Martine Fabre et Vincente Fortier, le juge de proximité, une nouvelle offre de justice: Droit et justice, printemps- Eté, 2007."Points négatifs peuvent être soulevés quant au deroulement et a' l'organisation de audiences". 
- The district court's judge may replace the nearby courts' in case of absence, excuse, or failure to reach the equilibrium. The judge run the hearing in its capacity as a district court $\left({ }^{1}\right)$

- Insufficiency of judges employed in the nearby courts owing to the overall decrease in the number of applicants to this job. Of paramount factors is the underestimated salary paid to the judges. Notably, it is a voluntary work that takes time and effort beside their main job.

- Failing to decide and lacking the profound legal knowledge and practice, judges of the nearby courts may recourse to the ones of the district courts in case of a claim of a critical legal issue or a serious legal interpretation or in case of a contract dispute $\left(^{2}\right)$. The judge of the nearby courts may, automatically or upon a request by either party, authorize the district courts' judge to consider and decide said cases $\left(^{3}\right)$.

- Territorially and emotionally close justice to litigants is achieved through judges of high legal experience and expertise capable of deciding critical and significant legal issues (trops ardus). Particularly, daily small claims can be solved by a district court judge dedicated to this mission without the need to a judge of the nearby courts $\left({ }^{4}\right)$. Furthermore; the nearby courts do not have distinctive procedures far cry of those of the district courts for resolving such claims.

In response to this objective criticism derived from the rules governing these courts in terms of formation, terms of reference, and lack of legal

${ }^{1}$ L'art. 232 -2 c.org. Jud. (Mod par la loi du 9 mars 2004 décide que en cas d'absence ou d'empêchement du juge de proximité ou lorsque le nombre de juges de proximités révélée insuffisant ; le juge d'instance exercice Les fonctions de juge de proximité."

${ }^{2}$ Les juridictions et juges de proximité " leur rôle concret en matière d'accès à la justice des petites litiges civils centre de Recherches critiques sur le droit, Décembre 2008. ".

${ }^{3}$ M.ch.lebreton " la justice de proximité. Un premier bilan pessimiste"l'art.231-5 c.org jud. D. 2004, Chron. 2808.

${ }^{4}$ N.G., "controverse autour de la qualité des juges de proximité" in le Monde, 16 févr. 2005, p. 6. 
experience and expertise; legal theorists called to cancel the nearby courts. Accordingly, the French legislature promptly issued Article no., Law 1862 of 2011 on ceasing the operation of the nearby courts as of the early of January, 2013 as amended to the early of January, 2015, then to the early of January, 2017. The district court and the small claims courts are competent to consider the cases of the nearby courts in which case the judges of the nearby courts not satisfying the legal term of employment will work as judicial officer at the first instance courts with limited competence. In addition, the president of the court may assign easy legal tasks to the judge that concur with their limited legal knowledge.

The district courts in France are currently competent to consider small claims not exceeding Euro 4000. They came back again achieving the same objectives and characteristics of the easy procedures and affordable costs.

\section{Third chapter}

\section{Emirates Experience}

\section{One-day Courts for Considering Small Commercial and Civil Disputes}

Within the framework of the principle of easy-access to justice and the idea of establishing courts close to litigants, Decree no. 38 of 2016 on establishing the one-day courts was issued by the president of the Judiciary council, Raas El-Khima Emirate and entered into force at the early of January, 2017. The decree incudes formation, procedures, and the legal force of judgments as follows:

Formation: One or more district court shall be established of one judge working at the courts of first instance.

Pecuniary Jurisdiction: The one-day court shall consider the commercial and civil claims not exceeding AED 20000. The court shall be competent to hear all types of commercial and civil claims unless otherwise stated by law or the claim fall within the specific jurisdiction 
of other courts as long as the value of the case does not exceed the court's monetary threshold.

Litigation Procedures: Under Article 3, litigation shall electronically be preceded from filing and registering the complaint and summoning the defendants. The court shall consider the claim and hear litigants at the same day.

Considering the Claim: The court shall consider the claim taking into consideration the procedural rules of publicity, freedom of defense, equality between parties, disclosing legal documents and information of both, and providing each party ample time to respond. The judge then shall consider the claim, prepare the legal interpretation, and hear the litigants in the same hearing or later on in a number of hearings as the case may be and as justice requires. Deciding the claim, the judge shall determine the fees of the claim and the fees of execution, and designate the party obligated to pay or exempted therefrom under law or a decree.

Legal Force and Execution of Judgments: Under Article 5 of the abovementioned decree, the judgment shall be final, binding by the force of law, unchallengeable though rendering from a court of first instance, and arbitrarily enforceable.

The judge of execution in the court of first instance shall be competent to enforce judgments rendering from the one-day courts and consider the summary and ordinary proceedings of the disputes.

Undoubtedly, establishing courts to consider small civil claims in one day ${ }^{1}$ ) or a few days, characterized by easy and quick procedures for

\footnotetext{
${ }^{1}$ Today's courts resembles Lithonia courts of summary proceedings which is competent to promptly settle commercial disputes in the place of the dispute. Such courts were established in France in the fifteenth century to settle commercial disputes in the great state fair where the dispute arises. They achieved great success and therefore became ordinary courts competent to consider commercial disputes, follows certain procedures
} 
optimum quality is another step toward effective justice. Yet, success of such courts depends on the quality and support of the judicial service which require providing training, technical skills, and professional development to the judicial officers and judges, use of high-end technology, recruiting professional and qualified judges, and updating the legal information retrieval.

Broadly speaking, the one-day courts shall objectively be evaluated following a reasonable period of time through the type and number of cases considered and the nature of judgment rendered and executed.

\section{Conclusion}

In sum, the present research discussed three judicial experiences of procedural legal rules in different countries. The rules aim at granting easy access to justice by establishing courts close to litigants (e.g. the district and family courts of Egypt, the nearby and district courts of France, and the oneday courts of Emirates). Partially failed, such attempts reflect the legislatures' intentions to grant the right of litigation through effective mechanisms of justice such as establishing nearby courts of litigants. The courts save costs and efforts of transportation and ensure quick settlement of disputes owing to their jurisdiction over small claims and disputes which require less time and effort. Consistently, the Egyptian legislature shall reconsider the rules and procedures governing litigation in Egypt, eliminate defects thereof, enforce existing legislative texts, think twice prior to modernizing existing legislation or adopting other countries' procedural rules, and structurally, administratively, technologically, and technically reform justice.

and ends with a judgment - for further information, see Emam, S. (2014). The Commercial Courts under the French Law. Dar El-Nahada El-Arabia. pp. 24-25. 
